\title{
Digitalisation is (not) strategy for Micro Business Stability: TAM Extended Model
}

\author{
Nia Kurniati Bachtiar ${ }^{1}$, Faqiatul Mariya Waharini², Juhaini Jabar ${ }^{3}$ \\ \{niakurniatibachtiar@ummgl.ac.id $\left.{ }^{1}\right\}$ \\ Management, Universitas Muhammadiyah Magelang, 56123, Indonesia ${ }^{1}$ \\ Accounting, Universitas Muhammadiyah Magelang, 56123, Indonesia ${ }^{2}$ \\ Faculty of Technology Management and Technopreneurship, Universiti Teknikal Malaysia Melaka, \\ Hang Tuah Jaya, 76100 Durian Tunggal, Melaka, Malaysia ${ }^{3}$
}

\begin{abstract}
The 4.0 era is a time where businesses have less-barriers and are interconnected in real time by which innovation is necessary and the internet is an imperative tool to survive. Digital businesses as a result of innovation grow rapidly. The number of customers that trade digitally shows a drastic increase and businesses are forced to adopt new technologies in their business. The research aims are threefold; 1 . to discuss what substantial variables affect adopter characteristics, 2. to elicit technical reasons that avoid the technology and innovation adoption, and 3. to uncover resistance reasons in adaptation innovation in micro businesses. Furthermore, this research was conducted to test TAM extended model by interviewing 1000 mobile street vendors in Magelang, Temanggung, Wonosobo, Purworejo, Salaman and Sawangan. After conducting a mixed-method analysis, this research has not only discovered the main variables affecting adopters' characteristics; additionally, this research has discovered an in depth understanding behind the reason why digitization is not a strategy for micro business stability and survival.
\end{abstract}

Keywords: Digital business, Innovation, TAM, Micro business, Mobile street vendors, Entrepreneurship

\section{Introduction}

When we enter industrial revolution 4.0, everybody assumes that the world is interconnected, people may trade globally without considering logistic barriers, everything is real time and the internet is the most important thing to survive. The same thing happens in the business world, business people depend on their business operations through the internet and technology. Businesses turn digital and Governments try hard to assist micro and small businesses to maximise technology usage in their business [4], [24]. The substantial effect of technology and the internet in business leads researchers to having an in-depth discussion about both elements. Hence, research relating to the utilization of technology in business is emerging both for large organisations and Small and Medium Enterprises (SMEs). However, most countries have more micro and small businesses than larger ones and it is common knowledge to state that micro businesses have lower digitalisation knowledge and resources. For this matter, it is significant to research how far digitalisation can be implemented in micro businesses and can they adapt to it.

Pursuing innovation in small business is not novel research. Bos-Browers [3] tried to combine innovative characteristics and sustainable innovation as keys to SMEs innovation. 
Harris et al. [5] explained that Business Improvement Method (BIM) and Total Quality Management (TQM) contribute to innovation implementation in SMEs. Aherty and Stephen [1] declared that innovation in SME is not a fiction, meaning that it can be achieved as long as they maximise their network and simplify the innovation process. The authors also underlined the flexibility and the ability to communicate quickly may lead to faster innovation process in SMEs. Aside from those, open innovation, social condition, and knowledge capabilities are also mentioned as reasons in pursuing innovation by SMEs [11], [19], [20].

Narrowing it down to micro business, innovation in this business is not deeply discussed yet. Roper and Hewitt-Dundas [18] investigated Schumpeter's creative destruction to find out market-based and supplier-based collaborative that successfully pursue innovation to these newto-market businesses. Bachtiar [2] stated that pursuing innovation in micro business is possible as long as business owners implement two innovation approaches such as: inclusive and collaborative innovation. However, previous research does not discuss the basic questions faced by all micro businesses' owners. Do they need to innovate? Does innovation help their business? How far will innovation help their business to sustain and grow?

Answering those questions is considered significant to build innovation awareness, start the innovation process and finally implement innovation approaches in micro businesses. In order to do so, a basic framework as Technology Acceptance Model (TAM) will be utilised in bridging the gap between theory and practice and to enrich our knowledge about micro business innovation. TAM as introduced by Fred Davis in 1989 has been through several developments. Venkatesh \& Davis [22] replaced attitude and intention with behavioral intention. The authors then expanded the model in 2000 by describing perceived usefulness in subjective norm, image, job relevance, output quality and result demonstrability. On the top of that, experience influences perceived usefulness and subjective norm to intention to use. Lastly, voluntariness becomes one cause of intention to use. However, this study will utilize the extended TAM model whereby it included the: 1. Effects of entrepreneur character towards experience and the intention to use as well as perceived usefulness; 2. Entrepreneurial know-how impact on perceived usefulness and competitive reason; and 3. Government support effect on intention to use a certain technology [21].

Aside from the theory and business size used in this research, research objects also play an important role in shaping the novelty of this research. Developing countries have a multitude of street vendors where most of them have not implemented any modern technology due to their unfamiliarity to those technology and innovation. Taking this scenario into consideration, this research has chosen and interviewed 1000 mobile street vendors in several cities of Central Java, Indonesia that fit the respondent characteristics to fulfill this study's objectives. This research aims to find significant variables that affect adopter characteristics for digital business, to answer the core question of innovation, the need of innovation in micro businesses, to investigate the role of innovation in micro business stability and lastly, how far it helps them to survive.

\section{Methods}

This study conducted a mix-method perspective due to its advantage to test hypotheses subsequently getting more in-depth findings to find solution to the issue [15]. mixed-method research provides a voice to study participants and ensure that study findings are grounded in participants' experiences. The quantitative perspective proposed hypotheses to be tested. 
Validity and reliability tests are carried out as well as multiple regression analysis. Apart from that, Qualitative perspective was employed to enrich the analysis by gaining more info from interview.

Data collecting process was started by distributing 1200 questionnaires to mobile street vendors around Central Java province include: Magelang, Temanggung, Wonosobo, and Purworejo. We used convenient sampling method and and 202 of the questionnaires were invalid and resulted 1000 valid questionnaires. Aside from that, for qualitative approach, sample taken from total respondents by categorizing it's kind of business, age of vendors and education level to be eligible as research samples. Samples then participated in structured interviews where variables from that interview were collected to be able to form a small group who are eligible to follow the in-depth interview. In Depth interview is crucial to construct data, find the answer of research questions and form a proposed model for this research. qualitative analysis is important to test the TAM extended model framework to assure whether the model is well implemented or need to be constructed for this research.

\section{Results and Discussion}

\subsection{Quantitative result}

Respondent background data is shown in Table 1. Based on gender, the number of male mobile street vendors is more than the number of female mobile street vendors with a percentage of 77.6\%. Based on age, 294 people are between 25-35 years old and 281 people are 36-45 years old and rest of them are scattered apart of that range. Regarding education, 392 respondents have only completed education up to Senior high school and 354 through Junior high school. Most of the mobile street vendors own a food business (77.8\%) and most have been running their business for more than 5 years $(37.6 \%)$.

For validity and reliability testing, the sig. scores of Pearson correlation test are less than 0.05 , so all instruments are valid. Then, all reliability coefficient values (Cronbach's Alpha) are greater than 0.6 , so it can be concluded that all data are reliable. Before any statistical analysis was done, all negative statements were recoded. Second, a factor analysis was conducted on all statements for innovation characteristics and all statements for innovator categories. For innovation characteristics, eight factors were produced. After reliability tests were done for each of these factors, only five remained. Based on the statements in each factor, the factors were then labelled. Factor 1 , labelled trialability, consists of 8 statements $(\alpha=0.944)$. Factor 2 , labelled relative advantage, consists of 5 statements $(\alpha=0.935)$. Factor 3 , labelled complexity, consists of 7 statements $(\alpha=0.881)$. For innovator categories, there were 18 statements in the instrument. Factor 1 was labelled innovator with 12 statement $(\alpha=0.942)$, Factor 2 was labelled late majority with 6 statements $(\alpha=0.809)$. 
Table 1. Respondent's background

\begin{tabular}{lcc}
\hline Item & Frequency & Percentage \\
\hline Gender & 776 & \\
Male & 224 & $77.6 \%$ \\
Female & & $22.4 \%$ \\
\hline Age & 162 & \\
Less than 25-year-old & 294 & $16.2 \%$ \\
25-35 years old & 281 & $29.4 \%$ \\
36-45 years old & 179 & $28.1 \%$ \\
46-55 years old & 84 & $17.9 \%$ \\
above 55 years old & & $8.4 \%$ \\
\hline Education & 22 & \\
Non-educated & 204 & $2.2 \%$ \\
Elementary school & 354 & $20.4 \%$ \\
Junior high school & 392 & $35.4 \%$ \\
Senior high school & 8 & $39,2 \%$ \\
Diploma & 20 & $0.8 \%$ \\
Bachelor's degree & & $2 \%$ \\
\hline Type & 778 & \\
Food & 222 & \\
Non-food & & \\
\hline Entrepreneur duration & 134 & \\
Less than 1 year & 317 & $13.4 \%$ \\
1-3 & 173 & $31.7 \%$ \\
$>$ 3-5 & 376 & $17.3 \%$ \\
$>$ 5 & & $37.6 \%$ \\
\hline
\end{tabular}

Table 2 shows four innovation characteristics for why innovation was adopted by the respondents. The dimensions are relative advantage, compatibility, complexity, and trialability. As indicated, trialability was identified as the highest (mean 3.135) among respondents. It means the innovation must have trialability; that is, it can be tested for a limited time without adoption.

Table 2. The Mean Score for the Innovation Characteristics of mobile street vendor

\begin{tabular}{lccccr}
\hline & $\mathbf{N}$ & Minimum & Maximum & Mean & Std. Deviation \\
\hline Relative Advantage & 1000 & 1 & 5 & 3.122333 & 1.071533 \\
Complexity & 1000 & 1 & 5 & 3.068143 & 1.026720 \\
Trialability & 1000 & 1 & 5 & 3.135625 & 1.084110 \\
Innovation & 1000 & 1 & 5 & 3.109150 & 1.061391 \\
Characteristics & & & & & \\
\hline
\end{tabular}

Table 3 shows that the mobile street vendor is in the late majority (mean 3.4099) adopters' category. For them, adoption may be both an economic necessity and a result of increasing network pressure from peers. The late majority approach innovations cautiously, and do not adopt innovations until most others have done so. 
Table 3. The Mean Score for Adopters' Categories of mobile street vendor

\begin{tabular}{llllll}
\hline & N & Minimum & Maximum & Mean & Std. Deviation \\
\hline Inovator & 1000 & 1 & 5 & 3.188917 & 1.01848167 \\
Late Majority & 1000 & 1 & 5 & 3.213000 & 0.94722167 \\
$\begin{array}{l}\text { Adopters' } \\
\text { Categories }\end{array}$ & 1000 & 1 & 5 & 3.200958 & 0.98285167 \\
\hline
\end{tabular}

A correlation analysis was conducted to test the relationship between the factors. Table 4 shows a strong positive relationship between innovation characteristics and adopter categories $(\mathrm{r}=0.834, \mathrm{p}=0.000)$. Meanwhile KPI and learning barriers are not significant in this prediction $(\mathrm{p}>0.05)$ indicating there is no relationship between these two factors.

Table 4. Correlation Analysis

\begin{tabular}{|c|c|c|c|c|c|}
\hline & & KPI & $\begin{array}{c}\text { Inovation_cha } \\
\text { racteristics }\end{array}$ & $\begin{array}{l}\text { Adpters_char } \\
\text { acteristic }\end{array}$ & $\begin{array}{c}\text { Learning_bar } \\
\text { riers }\end{array}$ \\
\hline \multirow[t]{3}{*}{ KPI } & Pearson Correlation & 1 & .028 & .012 & -.011 \\
\hline & Sig. (2-tailed) & & .380 & .696 & .787 \\
\hline & $\mathrm{N}$ & 1000 & 999 & 999 & 594 \\
\hline \multirow[t]{3}{*}{ Inovation_characteristics } & Pearson Correlation & .028 & 1 & $.834^{* *}$ & .017 \\
\hline & Sig. (2-tailed) & .380 & & .000 & .677 \\
\hline & $\mathrm{N}$ & 999 & 1000 & 1000 & 594 \\
\hline \multirow[t]{3}{*}{ Adpters_characteristic } & Pearson Correlation & .012 & $.834^{* *}$ & 1 & .001 \\
\hline & Sig. (2-tailed) & .696 & .000 & & .975 \\
\hline & $\mathrm{N}$ & 999 & 1000 & 1000 & 594 \\
\hline \multirow[t]{3}{*}{ Learning_barriers } & Pearson Correlation & -.011 & .017 & .001 & 1 \\
\hline & Sig. (2-tailed) & .787 & .677 & .975 & \\
\hline & $\mathrm{N}$ & 594 & 594 & 594 & 594 \\
\hline
\end{tabular}

Quantitative analysis (Table 5) examines the effect of internet usage ability, innovation characteristics, and learning barries on the adopter category. The regression analysis results show that the characteristics of innovation affect the adopter (Sig. $=.000$ ), while the other two variables have no effect $(\mathrm{Sig} .=0.397$ and 0.579$)$.

Table 5. Regression Analysis Predicting Adopters' Categories

\begin{tabular}{llll}
\hline Independent variable & $\mathbf{6}$ & $\mathbf{t}$ & Sig \\
\hline KPI & -.080 & -.847 & .397 \\
Inovation_characteristic & $.933 \mathrm{~s}$ & 35.011 & .000 \\
Learning_barriers & -.056 & -.555 & .579 \\
\hline Notes: Dependent variable: Adopters' category; *statistical significant at $\mathrm{p}<0.05 ;$ Adjusted R2=0.675; F \\
$=408.615, \mathrm{Sig}=0.000$ & &
\end{tabular}

\subsection{Qualitative Result}

While quantitative perspective tested hypotheses, the qualitative approach used in this theory tried to enrich previous theory and findings regarding technology applied in micro business. This approach emphasised that apart from innovation characteristic, internet capability 
and learning barriers, micro business actually faced deeper and basic technical problems in order to commit digital business.

Interview result showed that most interviewees found difficulties in implementing technologies in their operational, as recorded:

"It is difficult to handle both offline and online order when we are not too attached to technology like smartphone and mobile application" (Respondent 7)

Apart from that, infrastructure and media were considered problems as well, as cited:

"Most roads are bumpy in my operational area, so it's difficult to push my cart to the customer if they call”. (Respondents 1,3,4,5)

"I don't have any smartphone". (Respondents 8,9)

"Not all area has good Internet signal and If I have to go online, it means I have to always buy internet quota and it will cost me a lot" (Respondents 2,3,5,10)

Interview also resulted basic reason that avoid micro business to jump to digital business, such as lack of internal awareness, determination, need and have more external barriers to enter digital business. However, alike the quantitative analysis, they are more likely to be digitalized when most others do so.

Finally, the last aim of this research is to test TAM Extended model. That model explained the need of all elements as causes and keys to enter digital business. This TAM extended model includes entrepreneurship know-how, entrepreneurship character, competitive reason and government support as a complete solution to business digitalisation, as we can see in figure 1 below:

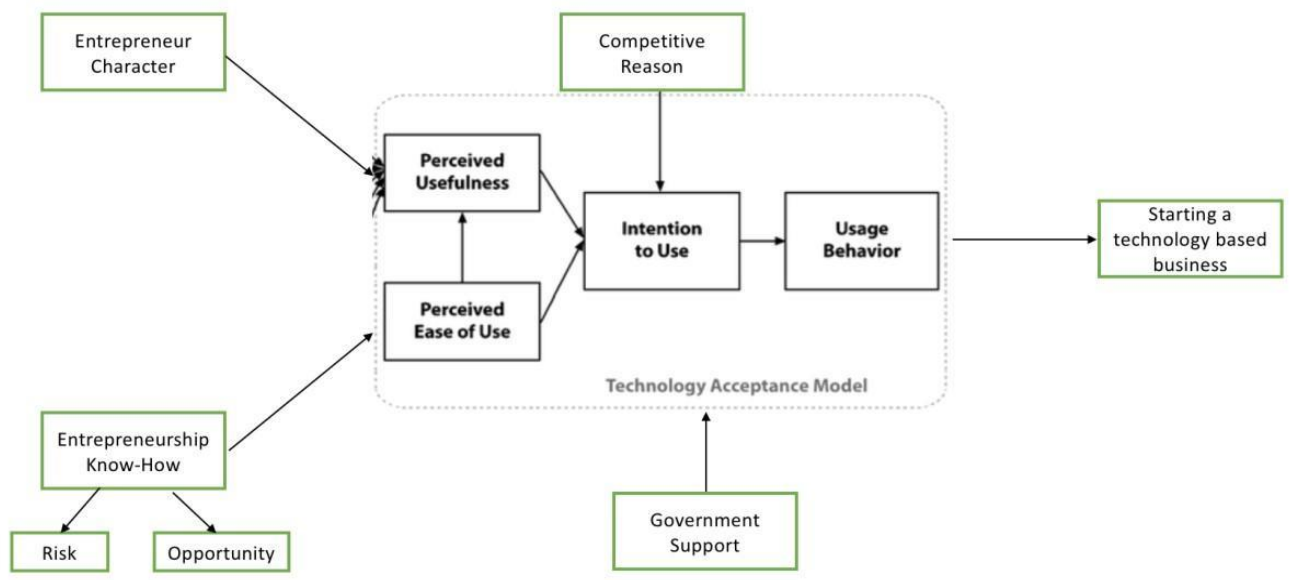

Fig. 1. TAM Extended Model [21]

Even though the model is considered as a complete solution to be digitalized, our research objects are not prepared for that. They do agree with all points, apart of competitive reason. Competitive reason as one substantial element in the model in fact considered by research objects in contrary way. They cited that:

"Too many competitors who sell the same items" (All respondents)

"There are numerous competitors who operate digitally" (Respondents 3,6,7,9,10)

"Walking around neighborhood is more profitable than selling online which have to many competitors already" (All respondents) 
Hence, when competitive reasons should have been a driver to jump to digital business, those mobile street vendors considered this point as challenge that need to be avoided. This is contrary to the framework used in this research where competitive reason is one of the reasons to jump to digital business.

Both qualitative and quantitative analysis above described that there is strong relationship between internet skill, innovation characteristic, learning barriers to adopter characteristic to digital business where the most significant element in innovation is trialability. Street vendors will pursue innovation when they see others commit to it and trialability becomes their first step into innovation. However, there is a high resistance for street vendors especially mobile ones to jump into digital business. This resistance is showed in qualitative approach done in this research. Unfamiliar to technology, competition, entrepreneurs' character, infrastructure, media are reasons to avoid this modern business.

Mostly this happens due to the lack of education, limited access to gadget and lack of intention and determination to start a digital based business. These findings supported previous study that indicated strong relation between internet knowledge, benefit in committing to digital business and policy to adopter characteristics in successful SMEs shifting to digital business [8], [9], [12], [14], [16]. Barriers on innovation as learning barriers and lack of determination were also in line with previous literatures [7], [10].

\section{Conclusion}

Innovation is a substantial process in business stability and survival. Innovation is well known and well adapted in large organisations; however, it happens on contrary in Micro, Small and Mediums Enterprises (MSMEs), especially to micro businesses. Whether the importance of innovation is well described, the implementation of it in Micro is challenging. Research conducted to 1000 mobile street vendors across Central Java province, Indonesia indicated that to have adopter characteristics in technology and innovation, ones have to have innovation characteristics. It clearly showed in data analysis that innovation characteristic affect adapter characteristics, where other variables such as barrier of learning and internet skill do not have any effect on adapter characteristics.

Following to that, in-depth interviewed was conducting to selected interviewees and gained some substantial information. Firstly, media and infrastructure are considered as technical barrier and lack of internal awareness, determination, needs are considered as internal barriers to resist them to jump to digital business. Lastly, they considered competitive reason is a basic reason to avoid digital business. This finding is contrary to TAM extended model that used to test the finding, where competitive reason is one of main elements to jump to digital business.

This research findings are substantial in increasing the awareness of digitalization for micro entrepreneurs, to indicate the importance of digitalization to enhance the economy of the micro entrepreneurs and community, to show how to increase the digital knowledge of mircro entrepreneurs, and lastly, to enlist how institutions/community can play a role to help improve the situation for the micro entrepreneurs 


\section{References}

[1] Aherty, U., \& Stephens, S. (2016). Innovation in micro enterprises: reality or fiction? Journal of Small Business and Enterprise Development, -

[2] Bachtiar, N. K. (2019). Pursuing Innovation in Micro Business. Is It Possible? The 1st Borobudur International Symposium (hal. 869-875). Magelang: Atlantic Press.

[3] Bos-Brouwers, H. E. (2010). Corporate Sustainability and Innovation in SMEs: Evidence of Themes and Activities in Practice. Business Strategy and the Environment, 417-435

[4] Handoko, F., Smith, A., \& Burvill, C. (2014). The role of government, universities, and businesses in advancing technology for SMEs' innovativeness. Journal of Chinese Economics and Business Studies.

[5] Harris, R., McAdam, R., McCausland, I., \& Reid, R. (2013). Levels of innovation within SMEs in peripheral regions: the role of business improvement initiatives. Journal of Small Business and Enterprise Development, 102-124

[6] Hashim, Junaidah. (2007). Information Communication Technology (ICT) Adoption Among SME Owners in Malaysia. International Journal of Business and Information 2(2), 221-240.

[7] Janita, I., \& Chong, W. K. (2013). Barriers of B2B e-Business Adoption in Indonesian SMEs: A Literature Analysis. Procedia Computer Science, Volume 17, 571-578.

[8] Jeon, B. N., Han, K. S., \& Lee, M. J. (2006). Determining factors for the adoption of e-business: the case of SMEs in Korea. Applied Economics, 38:16, 1905-191.

[9] Limthongchai, P., \& Speece, M. (2003). The Effect of Perceived Characteristics of Innovation on ECommerce Adoption by SMEs in Thailand. Proceedings of the Seventh International Conference on Global Business and Economic Development (hal. 1-13). Bangkok: SRRN.

[10] Madrid-guijarro, A., Garcia, D., \& Van auken, H. (2009). Barriers to Innovation among Spanish Manufacturing SMEs. Journal of Small Business Management, 47:4, 465-488.

[11] Maes, Johan, \& Sels, L. (2014). SMEs' Radical Product Innovation: The Role of Internally and Externally Oriented Knowledge Capabilities. Journal of Small Business Management, Vol. 52, Issue $1,141-163$

[12] Martin, L., \& Matlay, H. (2003). Innovative use of the Internet in established small firms: the impact of knowledge management and organisational learning in accessing new opportunities.

[13] Qualitative Market Research, Vol. 6 No. 1, 18-26

[14] Martínez-Román, J., \& Romero, I. (2017). Determinants of innovativeness in SMEs: disentangling core innovation and technology adoption capabilities. Rev Manag Sci 11, 543-569

[15] O'Cathain, A., \& Murphy, E. (2007). Why, and How, Mixed Methods Research Is Undertaken in Health Services Research in England: A Mixed Methods Study. BMC Health Services Research 7(1), 85.

[16] Ramsey, E., Ibbotson, P., \& Mccole, P. (2008). Factors That Impact Technology Innovation Adoption Among Irish Professional Service Sector

[17] SMES. International Journal of Innovation Management, 629-654

[18] Roper, S., \& Hewitt-Dundas, N. (2017). Investigating a neglected part of Schumpeter's creative army: what drives new-to-the-market innovation in micro-enterprises? Small Business Econ, 559-577.

[19] Sahut, J.-M., \& Peris-Ortiz, M. (2013). Small business, innovation, and entrepreneurship. Small Business Econ, 663-668.

[20] Spithoven, A., Vanhaverbeke, W., \& Roijakkers, N. (2013). Open innovation practices in SMEs and large enterprises. Small Business Economics, 537-562.

[21] Suhaeli, D., \& Bachtiar, N. K. (2019). Why Do (Not) Woman Entrepreneurs Jump Into Technology Based Business?. BizInfo (Blace) Journal of Economics, Management and Informatics, 10(2), 95-109.

[22] Venkatesh, V., \& Davis, F. D. (1996). A Model of the Antecedents of Perceived Ease of Use:

[23] Development and Test. Decision Science, 451-481.

[24] Verbano, C., \& Crema, M. (2016). Linking technology innovation strategy, intellectual capital and technology innovation performance in manufacturing SMEs. Technology Analysis \& Strategic Management, 28:5, 524-540. 